\title{
TINJAUAN TEOLOGIS TERHADAP BUDAYA PATRIARKAT DI INDONESIA
}

\author{
Eka Kristining Rahayu \\ Sekolah Tinggi Alkitab Tiranus \\ Jl. Cihanjuang Km. 5,2, Cihanjuang, Parongpong, Bandung Barat \\ eka.kristining@gmail.com
}

\begin{abstract}
Abstrak: Bangsa Indonesia adalah salah satu bangsa yang menganut budaya patriarkat. Tulisan ini ingin meneliti tentang pengaruh budaya patriarkat yang ada di Indonesia dan dampaknya bagi perempuan dalam masyarakat Indonesia. Dalam penelitian ini akan dilakukan tinjauan secara teologis terhadap budaya tersebut untuk melihat aspek positif dan negatifnya bagi perempuan di Indonesia, dan untuk mengetahui pandangan Alkitab mengenai peran perempuan dalam konteks sistem patriarkat. Tulisan ini akan melakukan studi literatur terhadap tulisan-tulisan penting yang bisa mendukung penelitian ini. Hasil dari penelitian menjelaskan bahwa budaya patriarkat secara teologis mempunyai dampak positif dan negatif bagi perempuan. Berkenaan dengan Alkitab, meskipun ditulis dalam konteks budaya patriarkat, tetap memandang perempuan sebagai makhluk ciptaan yang istimewa yang memiliki peran penting.
\end{abstract}

Kata Kunci: peranan perempuan, budaya patriarkat, masyarakat Indonesia, perempuan, teologi feminisme.

\section{THEOLOGICAL OBSERVATION ON PATRIARCHAL CULTURE IN INDONESIA}

\begin{abstract}
Indonesia is one of the nation that adhere to patriarchal culture. This article is going to study the influence of patriarchal culture and its impact on women in the Indonesian society. In this study, a theological review on the culture will be conducted to observe its positive and negative aspects for women in Indonesia, and to find out the Bible's view on the role of women in the context of patriarchal system. This article will conduct a literature study on important writings that could support this research. The result of this study explains that, theologically, patriarchal culture has positive and negative impact on women. In terms of the Bible, even though it was written in the context of patriarchal culture, it considers women as special creatures that have special roles
\end{abstract}

Keywords: women's role, patriarchal culture, Indonesian society, women, feminism theology. 


\section{PENDAHULUAN}

Perubahan zaman menjadi salah satu faktor besar dalam perkembangan peranan atau kiprah perempuan pada masa kini. Dibandingkan dengan masa lampau sekarang ini banyak ditemui perempuanperempuan yang bekerja di luar rumah (menjadi wanita karir), berkhotbah dalam ibadah-ibadah gereja, menjadi pemimpin suatu organisasi, dan masih banyak yang lainnya. Ini merupakan hal yang biasa terjadi pada saat ini. Namun, masih ada daerahdaerah yang menganggap pernyataan di atas sebagai situasi yang tidak normal, khususnya daerah yang masih berpandangan patriarkat.

Perkembangan peran perempuan memang mengalami peningkatan tapi ada sebagian orang yang masih belum merasakan perkembangan yang signifikan dan menggembirakan dalam beberapa hal, seperti dalam pendidikan dan organisasi Kristen. $\mathrm{Di}$ daerah-daerah tertentu perempuan masih banyak yang mengalami diskriminasi baik secara kedudukan dalam suatu organisasi ataupun dalam dunia kerja. Kemungkinan hal ini terjadi karena di Indonesia masih ada beberapa daerah yang memegang kuat dan menerapkan budaya patriarkat.

Melalui penelitian ini penulis ingin melihat seberapa besar dampak budaya patriarkat terhadap perempuan di masyarakat Indonesia dan juga nilai apa yang bisa diambil dari budaya tersebut ditinjau secara teologis. Ada tiga poin yang akan dibahas dalam artikel ini: (1) perempuan dan budaya patriarkat di Indonesia; (2) budaya patriarkat ditinjau secara teologis; (3) budaya patriarkat dan peranan perempuan dalam kaca mata Alkitab. Tidak hanya mengkritisi budaya patriarkat yang ada di Indonesia, pada bagian akhir penulis akan menguraikan masukan mengenai nilai postif dan negatif dari budaya patriarkat dan dampaknya bagi peranan perempuan yang tinggal dalam budaya tersebut dan penerapanya dalam pelayanan di Indonesia.

\section{METODE}

Dalam penelitian ini penulis melakukan studi literatur terhadap teks-teks penting yang berkaitan dengan budaya patriarkat untuk mengetahui dampak dari budaya tersebut kepada perempuan dalam kehidupan bermasyarakat, sumber yang dipakai oleh penulis adalah buku dan jurnal-jurnal yang masih relevan. Penulis menganalisa dan mencermati sumber-sumber yang digunakan untuk mendapatkan hasil penelitian yang sesuai dengan topik yang sedang dibahas. Selain menggunakan sumber-sumber tersebut penulis juga memakai Alkitab sebagai bahan analisa terhadap peran perempuan dalam konteks budaya patriarkat yang masih dianut kuat oleh masyarakat Yahudi pada masa itu.

Dari penelitian tersebut penulis juga menemukan nilai positif dan negatif yang dapat diambil dari budaya patriarkat yang dipegang kuat oleh suatu negara. Sedangkan ditinjau dari sudut pandang Alkitab yang penulisnya menganut budaya patriarkat melihat bahwa meskipun perempuanperempuan tidak terlalu menonjol dibahas bukan berarti Alkitab memandang rendah perempuan, Alkitab meskipun ditulis dalam konteks budaya patriarkat tidak menganut budaya tersebut karena Allah yang menjadi sumber utama Alkitab tidak menganut paham budaya apapun. Melalui hasil penelitian tersebut juga akan dilihat relevansinya bagi pelayanan di Indonesia yang masih menganut budaya patriarkat.

\section{HASIL DAN PEMBAHASAN}

\section{Perempuan dan budaya patriarkat di Indonesia}

Bangsa Indonesia adalah bangsa yang menganut paham budaya patriarkat. Kata "patriarkhal" atau "patriarkat" dalam KBBI 
memiliki arti suatu sistem pengelompokkan sosial yang sangat mementingkan garis turunan bapak, atau perilaku mengutamakan laki-laki daripada perempuan dalam masyarakat atau kelompok sosial tertentu. Dalam budaya ini kekuasaan ada pada tangan laki-laki, laki-laki memiliki hak penuh atas pengambilan keputusan. Syam dalam tulisannya mengatakan, "Kekuasaan ada di tangan laki-laki karena mereka dianggap sebagai makhluk yang rasional dari pada perempuan yang lebih emosional" (Syam, 2013, hlm. 1).

Budaya patriarkat sudah ada sejak zaman leluhur masyarakat Indonesia, dan budaya ini sudah mendarah daging dalam kehidupan orang-orang Indonesia sampai pada saat ini. Budaya patriarkat memiliki prinsip yaitu setiap laki-laki berkuasa dalam segala hal dibandingkan perempuan, dalam budaya ini perempuan harus patuh kepada laki-laki. Bahkan perkembangan budaya ini memicu munculnya ideologi patriaki yang menekankan kekuasaan kaum pria, seperti yang dituliskan oleh Wijaya:

Ideologi patriarki merupakan suatu ideologi yang menekankan kekuasaan bapak (kaum pria). Ideologi ini pun merupakan sebuah sistem sosial yang mendukung dan membenarkan predominasi kaum laki-laki yang mengakibatkan kontrol dan subordinasi perempuan, serta menciptakan ketimpangan atau ketidakadilan gender. Hal ini merupakan dominasi atau kontrol laki-laki atas perempuan, tubuhnya, seksualitasnya dan pekerjaannya, baik dalam keluarga maupun masyarakat (Wijaya, 2017, hlm. 106).

Salah satu daerah yang menganut budaya patriakhal adalah daerah Jawa. Dalam budaya tradisional Jawa kedudukan perempuan dianggap rendah, perempuan tempatnya di belakang bukan di depan. Dalam hal pendidikan, perempuan tidak diharuskan untuk mengenyam pendidikan yang lebih tinggi dari pada pria, masyarakat beranggapan setinggi apapun pendidikan seorang perempuan ujung-ujungnya nanti tempatnya tetap di dapur. Sampai-sampai muncul istilah 3M (macak, masak, manak), artinya adalah tugas perempuan adalah berdandan, memasak, dan melahirkan anak. Perbedaan pendidikan ini menjadi salah satu faktor terjadinya diskriminasi terhadap perempuan, selain itu umur serta jarak usia antara laki-laki dan perempuan yang terlampau jauh ketika menikah juga bisa memicu terjadinya sikap laki-laki yang menguasai perempuan. Citra Mustikawati mengatakan bahwa "masyarakat Jawa adalah masyarakat yang menganut sistem patriarki di mana laki-laki lebih diutamakan daripada perempuan" (Mustikawati, 2015, hIm. 68).

Budaya patriarkat ini mengakibatkan adanya kesenjangan antara laki-laki dan perempuan, laki-laki akan merasa lebih superior daripada perempuan. Akibat dari kesenjangan ini perempuan menjadi kesulitan dalam mengembangkan diri. Budaya patriarkat juga membuat perempuan tidak memiliki kebebasan dalam mengambil keputusan baik dalam keluarga maupun dalam ruang publik. Budaya inilah yang menciptakan adanya perbedaan gender antara laki-laki dan perempuan.

Pada tahun 1911 terbit sebuah buku yang berjudul Habis Gelap Terbitlah Terang. buku ini merupakan kumpulan surat-surat dari R. A. Kartini yang dikirimkan kepada teman-teman Belandanya. Isi surat itu adalah mengenai perjuangan wanita untuk bebas dari kurungan adat-istiadat dan kumpulankumpulan dari pemikiran R. A. Kartini mengenai rasa pedulinya terhadap kehidupan dan peranan perempuan dalam masyarakat. Kartini dalam tulisannya mencoba untuk memperjuangkan hak-hak perempuan sebagai manusia sepenuhnya, inilah makna emansipasi yang dimiliki oleh Kartini. 
Tetapi emansipasi pada saat ini tidak lagi memiliki makna yang mendalam seperti pada masa Kartini. Citra Mustikawati menuliskan dalam penelitiannya:

Makna emansipasi pada masa kini telah mengalami pergeseran makna, hal ini disebabkan oleh adat istiadat yang sudah berbeda dengan masa hidup Kartini. Pemahaman terhadap kata emansipasi telah mengalami pergeseran. Emansipasi dianggap sebagai perjuangan kaum perempuan untuk mendapatkan kesamaan hak dengan laki-laki (Mustikawati, 2015, hlm. 68).

Pemahaman makna yang mulai bergeser ini memberikan dampak terhadap budaya patriarkat yang ada di Indonesia. Di kota-kota besar Indonesia warna budaya patriarkat sudah semakin memudar. perempuan sudah mulai bisa menyumbangkan pendapatnya dalam masyarakat, dan semakin banyak perempuan yang mendapatkan pendidikan yang tinggi agar bisa mendapatkan hak yang sama dengan laki-laki di dalam kehidupan bermasyarakat. Tetapi budaya patriarkat tidak sepenuhnya hilang masih ada beberapa orang yang masih memegang teguh budaya tersebut.

Budaya patriarkat memiliki dampak positif dan negatif bagi masyarakat. Dampak negatifnya yaitu, perempuan mendapatkan perlakuan yang semena-mena dari laki-laki karena mereka merasa bahwa laki-laki lebih berkuasa daripada perempuan, sedangkan dampak positif dari budaya ini adalah perempuan tidak menyalahi kodrat kaum lakilaki sebagai seorang pemimpin dan perempuan juga tetap harus menaruh hormat kepada laki-laki sebagai makhluk sosial. Selain itu perempuan juga lebih bisa menghargai kaum laki-laki yang memang diciptakan untuk melindungi perempuan.

Bagian ini telah membahas budaya patriarkat yang ada di Indonesia dan perkembangannya yang mempengaruhi peranan perempuan dalam masyarakat. Pada bagian selanjutnya penulis akan membahas tentang tinjauan teologis terhadap budaya patriarkat.

\section{Budaya Patriarkat Ditinjau Berdasarkan Teologi Feminis}

Bagian sebelumnya telah membahas budaya patriarkat yang ada di Indonesia dan dampaknya terhadap peran perempuan dalam masyarakat di Indonesia, maka bagian ini akan membahas mengenai budaya patriakat serta dampaknya terhadap peranan perempuan dalam bidang religius ditinjau dalam kaca mata teologi feminis. Teologi feminis muncul pada abad ke-20, akhir tahun 1960-an di Amerika Utara. Teologi ini muncul karena ada banyak perempuan yang ingin disetarakan peranannya dengan laki-laki baik dalam masyarakat, gereja, dan pendidikan, mereka juga ingin mendapatkan kebebasan dari penindasan sebagai akibat dari sistem patriarkat. Menurut Sian, "teologi feminis bisa disebut sebagai usaha untuk menjelaskan kembali iman Kristen dari prespektif wanita sebagai kelompok yang tertindas" (Sian, 2003, hlm. 269).

Teologi feminis sangat menentang budaya patriarkat, karena budaya ini dianggap sebagai budaya yang menindas para kaum perempuan. Pada masa itu perempuan tidak mendapat kebebasan untuk mengambil keputusan, pergerakan perempuan juga terbatasi, mereka tidak diberi kesempatan untuk mengeluarkan pendapat mereka, dan sangat jarang ditemui seorang perempuan menjadi pemimpin, bisa jadi tidak ada sama sekali pemimpin perempuan pada masa itu. Di kehidupan beragama, ada beberapa gereja tertentu yang melarang perempuan untuk menjadi seorang pemimpin bahkan perempuan tidak mendapatkan kesempatan untuk berkhotbah dalam ibadah-ibadah besar di gereja. Dalam bukunya, Drewes dan Mojau mengatakan, 
Mengapa perempuan tidak bisa menjadi pendeta atau imam di gereja-gereja terntentu? Mereka juga mempersoalkan isi Alkitab yang disusun dalam konteks budaya patriakal, yang menekankan kekuasaan kaum laki-laki, juga mengenai sifat Allah di samping sebagai Bapa, apa Allah juga memiliki sifat keibuan? (Drewes \& Mojau, 2003, hlm. 60).

Dalam bidang keagamaan, teologi feminis memandang Alkitab sebagai tulisan yang memilki otoritas yang diinspirasikan oleh Allah sendiri dan diilhamkan kepada penulis Alkitab di mana penulis tersebut adalah manusia yang memiliki keterbatasan sehingga bisa saja terjadi ketidaksamaan antara firman Allah dengan kata-kata atau bahasa yang dipakai para penulis. Para feminis menganggap ada beberapa isi Alkitab yang tidak konsisten tentang perempuan, karena ditulis dan disusun oleh kaum pria yang berbudaya patriarkat, artinya adalah ada beberapa isi Alkitab yang menempatkan perempuan pada posisi yang sama atau bahkan lebih tinggi dari laki-laki, tetapi kadang sebaliknya. Para feminis berpendapat bahwa pandangan patriarkat tidak perlu dipakai dalam membaca teks-teks Alkitab, supaya bisa melihat berita tentang pembebasan kaum perempuan. Alkitab juga harus dilihat dari konteks pengalaman yang dialami oleh kaum perempuan.

Bagian ini sudah meninjau peranan perempuan berdasarkan teologi feminis, lalu apa kata Alkitab sendiri mengenai budaya patriarkat dan dampaknya terhadap peranan perempuan sebagai ciptaan Allah. Dalam bagian selanjutanya akan dibahas tentang budaya patriarkat dan peranan perempuan dalam Alakitab.

\section{Budaya Patriarkat dan Peran Perempuan Dalam Kaca Mata Alkitab}

Teologi feminis muncul karena kaum perempuan ingin terbebas dari penindasan sistem patriarkat. Para feminis memiliki pemikiran yang negatif tentang Alkitab karena ditulis dan di susun oleh kaum pria yang berbudaya patriarkat. Apakah pandangan para feminis terhadap Alkitab ini benar? Dalam bagian ini penulis akan menguraikan bagimana Alkitab memandang peranan perempuan dan budaya patriarkat.

Bangsa Yahudi sejak zaman dahulu adalah bangsa yang menganut paham budaya patriakat. hal ini dapat diketahui melalui setiap kisah yang ada dalam Alkitab. Dalam Alkitab, kisah-kisah perempuan sangat jarang sekali dimunculkan. Walaupun ada beberapa kitab yang memakai atau menuliskan kisah perempuan seperti kitab Ester dan kitab Rut, tetapi kisah mereka ditulis dalam porsi yang tidak terlalu banyak seperti kitab-kitab lainnya. Bahkan perempuan-perempuan yang memilki peran penting dalam mendatangkan Juruselamat hanya diceritakan sekilas saja. Ketika membaca Alkitab pembaca akan merasakan nuansa budaya patriarkat yang sangat kuat dari setiap kisah-kisah yang diceritakan.

Pertama-tama penulis akan melihat budaya patriarkat dari kaca mata Perjanjian Lama. Nuansa budaya tersebut sudah mulai terasa dalam kisah penciptaan. Allah menciptakan manusia yang pertama dengan gender laki-laki yang diberi nama Adam. Namun, dalam kasus ini Allah memiliki alasan dengan menciptakan Adam sebagai manusia yang pertama, yaitu Allah memberikan tugas dan tanggung jawab untuk memelihara serta berkuasa terhadap ciptaan yang lain (Kej. 1:27-28).

Budaya patriarkat juga terlihat pada bangsa Israel; hal ini bisa dilihat melalui seilsilah keluarga atau keturunan bangsa tersebut. Alkitab menuliskan silsilah keluarga bangsa Yahudi dengan lebih berpusat kepada pihak laki-laki. Alkitab juga menggambarkan peranan perempuan secara implisit dalam berbagai bidang. Wijaya dalam penelitiannya mengatakan bahwa, "Budaya patriakhal merupakan sistem yang diduga 
kuat mempengaruhi pemikiran masyarakat Israel dalam bersikap dan memperlakukan perempuan" (Wijaya, 2018, hlm. 136).

Dalam Perjanjian Baru budaya patriarkat juga masih dipegang kuat oleh orang-orang pada masa itu, khususnya oleh orang-orang Farisi. Injil Yohanes menuliskan kisah tentang seorang perempuan yang kedapatan berzinah. Pada kasus ini yang dibawa ke hadapan Yesus oleh orang-orang Farisi dan ahli-ahli Taurat untuk diadili hanyalah perempuannya saja, sedangkan laki-laki yang bersama dengan perempuan tersebut tidak ikut diadili (Yoh. 8:1-11). Penulis melihat adanya diskriminasi terhadap perempuan dalam kasus ini. Kemudian ketika Tuhan Yesus memberi makan lima ribu orang, yang dihitung hanyalah kaum laki-laki. Penghitungan seperti ini sudah ada sejak Perjanjian Lama ketika bangsa Israel dihitung untuk pertama kali pada saat ke luar dari Mesir.

Ron Sider mengatakan dalam tulisannya bahwa, "Pada zaman Yesus, apabila ada seorang laki-laki tampil dengan seorang perempuan di tempat umum, itu adalah sebuah skandal. Lalu kebanyakan bagian atau tempat dari Bait Suci terlarang bagi perempuan. Mereka juga tidak dihitung dalam perhitungan kuorum yang diperlukan untuk pertemuan sinagoge" (Sider, 2018, hlm. 115).

Alkitab dalam penulisannya memang dipengaruhi oleh budaya dan adat-istiadat bangsa Yahudi, karena para penulis Alkitab pada masa itu adalah orang-orang yang kehidupannya masih sangat dekat dengan kebudayaan Yahudi dan mereka juga memegang kuat kebudayaan tersebut. Oleh karena itu nuansa budaya patriarkat dalam Alkitab sangatlah kuat. Namun, bukan berarti Allah yang merupakan sumber dari setiap firman yang ada dalam Alkitab adalah Allah yang menganut budaya patriarkat, dan budaya-budaya lainya. Penulis juga beranggapan bahwa Alkitab tidak pernah bermaksud untuk merendahkan kaum perempuan karena perempuan juga merupakan ciptaan Allah dan segala yang diciptakan-Nya itu baik. Secara tersirat Allah menunjukkan bahwa sesungguhnya perempuan juga memilki peran penting dalam rencana-Nya.

Peran perempuan di Perjanjian Lama memang tidak terlalu menonjol dibandingkan dengan kaum pria karena pengaruh budaya patriarkat yang masih kental pada masa itu. Tetapi itu bukan berarti Alkitab merendahkan perempuan. Kitab Kejadian menuliskan bahwa perempuan diciptakan dari tulang rusuk laki-laki, dan Allah menyebutkan peran perempuan yang pertama kali adalah sebagai penolong bagi manusia pertama yaitu Adam (Kej. 2:18-23). Dalam Alkitab Penuntun kata penolong dipakai juga untuk menggambarkan Allah; perempuan diciptakan oleh Allah supaya menjadi teman yang mengasihi dan menolong kaum laki-laki untuk melaksanakan tanggung jawabnya.

Setelah kejatuhan manusia ke dalam dosa yang mengakibatkan rusaknya seluruh ciptaan, Allah berinisiatif untuk menyelamatkan manusia dengan mendatangkan seorang penyelamat, dan penyelamat itu adalah keturunan dari perempuan (Kej. 3:15). Secara tidak langsung perempuan memilki peran penting, yaitu untuk menghadirkan Juruselamat. Penulis juga melihat dalam Perjanjian Lama ada beberapa tokoh perempuan yang turut ambil bagian dalam kedatangan Kristus dan para perempuan ini bukanlah perempuan asli Yahudi yang merupakan umat pilihan Allah. Mereka adalah Tamar, Rahab, dan Rut. Pada Bilangan 27:1-11, kaum perempuan yang merupakan keturunan Manasye juga mendapatkan hak warisnya, ini juga merupakan bukti bahwa Allah tidak memandang rendah perempuan. Allah juga memakai perempuan untuk memberikan kemenangan kepada bangsa Israel ketika melawan raja Kanaan (Hak. 4:1-23). Masih 
banyak lagi perempuan-perempuan yang memiliki peran penting di dalam Alkitab, seperti Ester yang menyelamatkan bangsa Yahudi dari pembunuhan masal, Lea dan Rahel yang melahirkan kedua belas suku Israel, dan seorang gadis kecil pelayan Naaman yang menolong Naaman dalam menyembuhkan penyakit kustanya.

Sedangkan dalam Perjanjian Baru hampir di semua Injil akan ditemukan nama Maria yang menjadi ibu dari Yesus Kristus. Lukas 8:1-3 menceritakan tentang perempuan-perempuan yang melayani Yesus. Kemudian yang menjadi saksi kebangkitan Yesus pertama kali adalah para perempuan yang mengikuti Yesus. Dalam Perjanjian Baru juga ada beberapa tokoh perempuan yang menjadi murid-murid Yesus pada masa rasul-rasul, seperti Lidia, Dorkas, dan Priskila. Mereka dipakai Tuhan untuk membantu pelayanan para rasul. Paulus dalam Efesus 5:25 mengatakan bahwa perempuan itu sangat berharga sehingga kaum pria harus mengasihinya seperti Tuhan mengasihi jemaat, meskipun konteks ayat ini adalah tentang hubungan pernikahan, tetapi menurut penulis ini adalah suatu contoh di mana kedudukan perempuan itu setara dengan kaum pria di mata Tuhan. Masih ada beberapa ayat yang menunjukkan bahwa Allah tidak merendahkan perempuan, seperti: kolose 3:18-19 dan Titus 2:3-4. Pada zaman Yesus, Yesus dan para pengikut-Nya memperlakukan perempuan setara dengan laki-laki, kembali Ron Sider menuliskan bahwa:

Yesus tampil dengan perempuan di muka umum (Yoh 4:27), dan mengajar mereka teologi (Luk 10:38-42). la mengijinkan seorang perempuan (Luk 7:36-50), yang dikenal semua orang sebagai orang berdosa, untuk membasuh kaki-Nya dengan air mata dan menyekanya dengan rambutnya, mencium dan meminyakinya dengan minyak wangi, semuanya dilakukan di muka umum. Yesus mau setiap laki-laki dan perempuan bersama-sama di muka umum memberitakan kerajaan Allah. (Sider, 2018, hlm. 116-117)

Alkitab secara tidak langsung sudah membuktikan bahwa perempuan adalah ciptaan yang berharga di mata Allah sama seperti laki-laki. Meskipun Alkitab dituliskan dalam konteks budaya patriarkat yang masih sangat kuat, hal ini tidak serta merta menghilangkan keistimewaan perempuan dan peranannya di hadapan Allah. Menurut hemat penulis, Allah memilki maksud tersendiri dengan lebih menonjolkan peranan laki-laki dalam Alkitab; Allah ingin menunjukkan bahwa laki-laki merupakan wakil-Nya di dunia ini yang diberi tanggung jawab untuk menjadi pemimpin dan pengelola dari ciptaan lainnya dan perempuan ditempatkan di sisi laki-laki sebagai pendukung dan penolong dalam menjalankan tugas dan tanggung jawabnya.

\section{KESIMPULAN}

Dari tinjauan dan pembahasan mengenai budaya patriarkat dan dampaknya terhadap peran perempuan dilihat dari tiga sudut pandang, melahirkan beberapa pemikiran yang diungkapkan dalam beberapa kesimpulan. Kesimpulan-kesimpulan tersebut adalah:

Pertama, dalam budaya patriarkat di Indonesia, kedudukan perempuan masih di bawah kaum pria. Di daerah-daerah yang masih memegang adat-istiadat tradisional, pria lebih berkuasa dari pada perempuan. tugas perempuan adalah merawat keluarga dan hal-hal mengenai kerumahtanggaan. Perempuan dianggap tidak memerlukan pendidikan yang tinggi. Namun, setelah munculnya masa emansipasi wanita, peranan perempuan mulai berkembang, hal ini bisa terlihat dari semakin banyaknya perempuan-perempuan yang memiliki karier dan pendidikan yang sama dengan kaum pria. 
Kedua, munculnya teologi feminis di abad ke-20 merupakan sebuah respons dari kaum perempuan terhadap budaya patriarkat yang terjadi pada masa itu dan masa-masa sebelumnya. Kaum perempuan pada masa itu ingin mendapatkan kebebasan dari penindasan yang mereka alami sebagai akibat dari budaya tersebut. Melalui teologi feminis ini kaum perempuan ingin menjelaskan iman Kristen kepada perempuan lain yang tertindas menurut sudut pandang mereka. Teologi feminis ini memiliki dampak yang cukup besar di masa kini, salah satunya adanya emansipasi wanita, kesetaraan gender, dan peningkatan peranan perempuan.

Ketiga, Alkitab tidak memandang rendah kedudukan perempuan, dalam Alkitab dituliskan bahwa Allah menciptakan perempuan dan memberikannya kedudukan yang setara dengan kaum pria. Ada banyak kisah-kisah dalam Alkitab yang menceritakan tentang peranan perempuan mulai dari zaman Perjanjian Lama sampai ke Perjanjian Baru. Alkitab memang ditulis dalam konteks budaya patriarkat yang sangat kental, namun isi dari Alkitab itu sendiri tidak dimaksudkan untuk merendahkan atau meninggikan ciptaan Allah. Alkitab adalah tulisan yang diilhamkan oleh Allah dan isinya lebih menceritakan Allah itu sendiri.

Budaya patriarkat dilihat dari berbagai sudut pandang memiliki dampak positif dan juga negatif. Dampak negatifnya adalah kaum pria menjadi semena-mena kepada perempuan yang merupakan seorang yang ditunjuk langsung oleh Allah untuk menjadi penolong bagi laki-laki. Sedangkan dampak positifnya adalah perempuan akan lebih bisa menghargai laki-laki sebagai wakil Allah di dunia ini, kalau perempuan bisa menghargai dan menghormati laki-laki, maka mereka juga akan bisa menghormati Allah sebagai Sang Pencipta. Perempuan bisa menentukan prioritas utama mereka dalam menjalankan perannya, khususnya di tengah-tengah keluarga dan masyarakat.

Oleh karena itu, sebagai seorang perempuan perlu untuk mengetahui dan mengerti tentang paham budaya patriarkat agar mereka tidak melupakan kodratnya sebagai perempuan yang diciptakan untuk menolong kaum laki-laki dalam melakukan tugas dan tanggung jawab mereka. Budaya patriarkat juga mengajari untuk lebih menghormati laki-laki sebagai pemimpin mereka sehingga mereka tidak semenamena. Selain itu budaya ini juga mengajarkan kepada perempuan untuk tidak melupakan bahwa mereka juga memiliki peran penting dalam keluarga, yaitu untuk mengurus dan mengawasi rumah tangga dan mendidik anak-anaknya.

Relevansinya bagi pelayanan di tengah-tengah masyarakat Indonesia yang berbudaya patriarkat yaitu, masyarakat Indonesia walaupun menganut paham budaya patriarkat bukan berarti menjadikan budaya ini sebagai pegangan untuk menindas dan mendiskriminasi kaum perempuan, karena laki-laki dan perempuan memiliki kedudukan yang sama di mata Allah, Sang Pencipta, dan di atas kebudayaan yang bermacam-macam di dunia ini masih ada otoritas yang lebih tinggi yaitu Firman Allah di dalam Alkitab. Hendaknya manusia memperlakukan perempuan seperti yang Alkitab perintahkan sebagai penghargaan dan penghormatan manusia terhadap Allah Sang Pencipta. 


\section{DAFTAR RUJUKAN}

Alkitab dengan Kidung Jemaat. (2009). Jakarta: Lembaga Akitab Indonesia.

Alkitab Penuntun Hidup Berkelimpahan. (t.t.). Malang: Gandum Mas.

Drewes, B. F., \& Mojau, J. (2003). Apa itu teologi?: pengantar ke dalam ilmu teologi. Jakarta: BPK Gunung Mulia.

Mustikawati, C. (2015). Pemahaman Emansipasi Wanita (Studi Hermeneutika Makna Emansipasi Wanita Dalam Pemikiran R. A. Kartini Pada Buku Habis Gelap Terbitlah Terang). Jurnal Kajian Komunikasi, 3(1), 65-70.

Sian, L. I. (2003). Sebuah Tinjauan Terhadap Teologi Feminisme Kristen. Veritas: Jurnal Teologi dan Pelayanan, 4(2), 263-278.
Sider, R.(2018). Dalam Bagaimana Jika Injil adalah Kabar Baik Kerajaan? Stott, J. R. W., Misi Menurut Perspektif Alkitab (3 ed.). Jakarta: Yayasan Komunikasi Bina Kasih.

Syam, E. (2013). Representasi Perempuan dalam Masyarakat Patriakhal yang Tergambar dalam Antigone Karya Sophocles. Jurnal Ilmu Budaya, 10(1).

Wijaya, E. C. (2017). Perdebatan Peran Wanita Dalam Organisasi Kristen: Tinjauan Terhadap Isu Kepemimpinan Kontemporer. Evangelikal: Jurnal Teologi Injili dan Pembinaan Warga Jemaat, 1(2), 103-117.

Wijaya, E. C. (2018). Eksistensi Wanita Dan Sistem Patriarkat Dalam Konteks Budaya Masyarakat Israel. Jurnal Fidei, 1(2). 